\title{
LINE コミュニケーションにおける顔文字使用に対人関係が及ぼす影響
}

\author{
○山本恭子 ${ }^{1}$ 木村昌紀 ${ }^{2}$ \\ (神戸学院大学 ${ }^{1}$ 神戸女学院大学 ${ }^{2}$ )
}

Key words: emoticons, personal relationship, computer-mediated communication

\section{目 的}

対面では, 他者との関係性によって表情表出が異なる(e.g. , 山本·鈴木, 2005)。顔文字は CMCにおける表情ととらえられ, 顔文字の使用も相手との関係性によって異なると推察される。

対人関係に応じて顔文字の使用量が異なることの背景には, 透明性の期待や公的自意識の変化があると考えられる。親し い友人関係では，相手は自分のことを理解してくれるという 透明性の期待が高まることにより, 顔文字があまり使用され ないのに対して, 未知関係では一時的に公的自意識が高まる ことで，顔文字の使用が促進されることが推測される。

本研究は, 二者間で LINE を用いてコミュニケーションを行 い, 対人関係が顔文字の使用量に及ぼす影響を実験的に検討 する。その際，透明性の期待と公的自意識に注目した。

\section{方 法}

実験参加者 女子大学生 40 名 (平均年齢 20.45土1.13 歳)。 友人群 10 組 20 名, 未知群 10 組 20 名。

質問紙 1)公的自意識：自意識尺度（菅原，1984）の公的自 意識の項目を，実験中の状態を問うように改変した 9 項目を 使用した。7 件法（ $\alpha=.82 ） 。 2)$ 透明性の期待：独自に作成し た 8 項目を使用した。 7 件法 $(\alpha=.88)$ 。3)LINE の利用傾向 : 普段の LINE の利用傾向について尋ねた。

手続き 未知関係または友人関係の 2 人 1 組で実験を行った。 LINE を介して会話してもらう実験であることを説明した後, 未知群では LINE のアカウントを交換してもらった。次に, 各 参加者を個別の実験室に案内した。その後,ペア間で「大学 生活」をテーマにLINEによる会話を行ってもらった。時間は 20 分であった。終了後, 質問紙に回答を行ってもらい, LINE の情報を提供してもらうことへの同意を求めた。

LINE 情報の解析 参加者に提供してもらった LINE のスクリ ーンショットをもとに,「顔文字」,「絵文字」,「スタンプ」, 笑いを示す「W」と「笑」,「吹き出し」, および,「文字」の数 をカウントした。

\section{結 果}

LINE 情報 LINE のやり取りの総量の差について検討する ため,「吹き出し」と「文字」の数について群を要因とする対 応のない $t$ 検定を行った。その結果,「吹き出し」 $(t(25.46)=3.79, \not \ltimes .01, \alpha=1.23)$ と「文字」 $(t(27.24)=3.01$, $p \times .01, d=0.95)$ ともに有意な差が認められ, 友人群の方が未 知群よりも数が多いことが示された。

図 1 に「顔文字」,「絵文字」,「スタンプ」,「W」,「笑」の個 数の条件別平均値を示した。上述したように，文字数に差が 認められたことから，その影響を取り除くため，以下の分析 においては，各個数を文字数で除した割合を用いた。友人群 と未知群における差について検討を行うため, 対応のない $t$ 検定を行った。その結果, 「顔文字」 $(t(38)=2.78, p<.05$, $d=88)$ ，および,「W」( $t(38)=3.27, p<.01, d=1.04)$ におい て有意な差が認められた。「絵文字」 $(t(38)=1.30, n . s$. ,

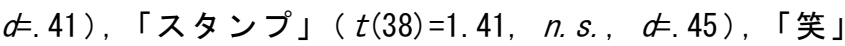
$(t(38)=1.55, n . s ., d=49)$ では有意な差は得られなかった。 「顔文字」は未知群の方が多く使用し、「W」は友人群の方が多 く使用することが明らかとなった。

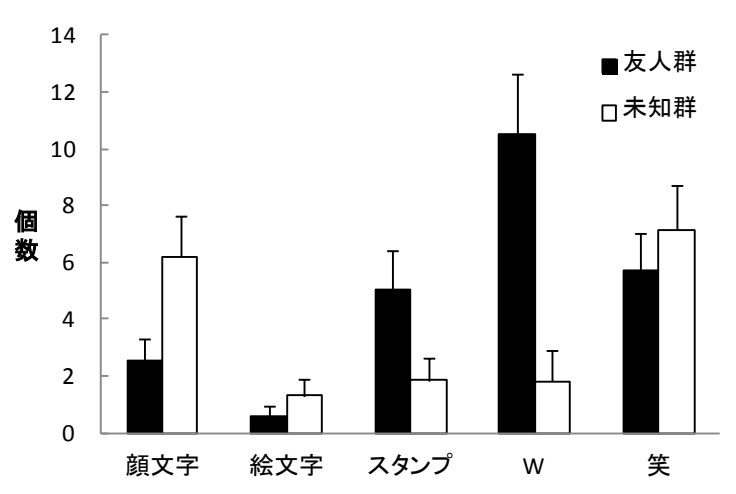

図 1 顔文字，絵文字，スタンプ，w，笑の使用数の 条件別平均值と $\mathrm{SE}$

質問紙 透明性の期待と公的自意識（図 2) について，群 間の差を検討するため, 対応のない $t$ 検定を行った。その結 果, 透明性の期待では有意傾向 $(t(33.62)=1.81, p<.10$, $d \neq .57)$, 公的自意識では有意な差 $(t(37)=3.03, p<.01, d \neq .97)$ が認められた。透明性の期待は友人群で高い傾向があり, 公 的自意識は未知群で高いことが示された。

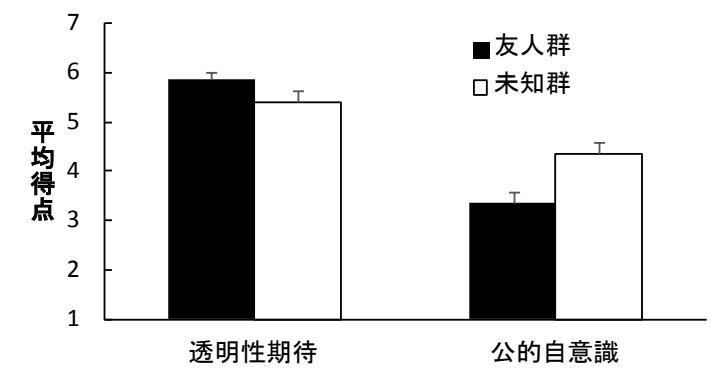

図 2 透明性の期待と公的自意識の条件別平均値と SE 考 察

未知群の方が友人群よりも顔文字の使用量が多いことが見 いだされた。この結果は, 親しい関係の方が顔文字や表情表 出が多いという報告（加藤・赤堀, 2005; 加藤ら, 2006 : 山 本・鈴木，2005）とは異なるものである。

会話後に測定した透明性の期待は友人群の方が未知群より も高い傾向があり, 公的自意識は未知群の方が高かった。友 人群は会話相手に自分の気持ちが十分伝わっていると感じる ために, 感情伝達を補足するための顔文字の使用量が少ない ことが考えられる。一方, 未知群では公的自意識が高まって おり, 相手からの評価を気にして, 親しみやすさの自己呈示 を行うために，顔文字を多く使用した可能性が考えられる。

笑いを意味する「W」と「笑」に関して，「W」では友人群の 方が未知群よりも使用量が多かった。「W」は「笑」に比べて カジュアルであり，嘲笑のニュアンスを含むリスクがある。 友人群では透明性の期待が高く, w を誤解されるとは感じな いために，使用量が多いことが推察される。

\section{謝 辞}

本研究は, 今村絵里さんの神戸学院大学 2015 年度卒業論文 に基づくものであり, 本発表はそれらを再分析・考察したも のである。データの提供について，ここで謝意を表す。

(Kyoko YAMAMOTO, Masanor i KIMURA) 